\title{
The effect of some heavy metals on oats in a pot experiment with three different soil types
}

\author{
AsbJørn SORTEBERG \\ Department of Soil Fertility and Management, Agricultural University of Norway
}

\begin{abstract}
An account is given of a pot experiment comprising all combinations of 5 heavy metals (cadmium, cobalt, lead, mercury and nickel), 3 rates of each metal $(0.50$ and $250 \mathrm{mg} / \mathrm{pot}), 2$ rates of lime, and 3 types of soil (clay soil, peat soil, and sandy soil).
\end{abstract}

Crop yields of grain and straw are given in Table 2. Low addition of the metal (50 $\mathrm{mg} / \mathrm{pot}) \mathrm{has}$ had slight or no effect on the yield size. The high rate of metal $(250 \mathrm{mg} /$ pot) of some of the metals has induced definite to heavy yield reductions. Nickel has led to a heavy yield decrease in all soil series both in grain and straw after light liming. The yield reduction is to a certain extent or completely eliminated after heavier liming. Mercury has induced a near complete crop failure in the sandy soil series at both lime rates. Some yield reduction is obvious also in the other soil series, in clay soil only after light liming. Cadmium has reduced the straw yields in peat soil after both lime rates. Clay soil shows grain yield reduction at heaviest liming, while no yield reduction is detectable in the sandy soil. Cobalt has induced some degree of yield reduction in all soil types, most of all in clay soil after light liming. Lead has had no effect on the yield size.

The heavy metal content in the crop is presented in Table 3. Apart from lead, the relative content increases very heavily with increased metal application. The content at times proves essentially higher in the crop from peat soil and sandy soil than in crop from clay soil. The content of cadmium, nickel and cobalt is lower at heavy liming compared to light liming. This is particularly characteristic of the crop from clay soil and sandy soil. The effect of heavier liming on the mercury and lead uptake is equivocal. For nickel, the relative content is essentially higher in the grain than in straw. The content of other metals is higher in the straw. The lead content in particular is much higher in straw than in the grain.

In addition to the crop experiment, all treatments have included one parallel pot without plants. At the harvesting time, samples were taken from these pots for chemical analysis. The heavy metal content was determined after extraction by an AL-solution (Table 4). Wide variations appear between metals and soil types with regard to the recovered amounts of applied metal. Mercury shows a characteristically low AL-soluble recovery, only 1 to 2 per cent at the highest application rate. Also of lead, only a small amount of the applied substance exists as AL-soluble. With regard to the remaining metals, nearly all have been recovered as AL-soluble by a heavy application of cadmium to sandy soil at light liming. In other cases the percentage recovery falls within the $20-70$ range, the lower figures often pertaining to clay soil and the higher ones to peat soil.

A description of plants influenced by retarded growth, and symptoms of toxicity, are given. 


\section{Introduction}

From a purely chemical-physical point of view a heavy metal is defined as a metal of a given specific weight. The reported weight limit varies slightly.

Heavy metals have recently acquired wider importance through their impact on living organisms. This adds also a biological aspect to the heavy metals, where the biological effect, at least in cases of high concentrations or lasting influence, is detrimental. All elements may then be included, metals as well as metalloids, "heavy" as well as "light" ones, whose occurrence in the environment may be detrimental to living organisms.

Several of the heavy metals, such as mercury, cadmium and lead, are normally regarded exclusively as biologically unfavourable. Others are detrimental in larger amounts, though essential to the organism in smaller ones (trace elements to plant and animals).

The prospect of detrimental effects from heavy metals has become more topical in plant production lately through the utilisation of sewage sludge. Local soil areas may also be affected by the mining industry, industrial plants etc. As a result, plants may be enriched in heavy metals. Even in a virginal natural environment the soil may be locally enriched in heavy metals, thus causing a heavy increase in those metals in the vegetation. Industrialising normally leads to a demand for refuse disposal of a variety of materials of differing heavy metal content. The fact should be faced that a recipient for such refuse might be the soil. Sound knowledge on the reaction of the soil and the plants to heavy metal application therefore becomes desirable.

\section{A pot experiment with different soil types and increasing rates of heavy metals}

Experimental design. The different soil types

Over the last 3-4 years the Department of Soil Fertility and Management, the Agricultural University of Norway, has conducted pot experiments with application of varying amounts of heavy metals in cereals. The overall intention has been to acquire a more thorough knowledge about the detrimental effect of such elements, e.g. possible diagnostic signs in the plants of an overdose, the approximate amount or threshold value for application, and the reaction of the heavy metal content on application. It is selfevident that these conditions may vary widely, depending on soil type, soil reaction, plant species, etc.

A relatively comprehensive pot experiment in oats was initiated in the spring 1973, the following gives an account of the current results from this experiment. The experiment comprises 6 different soil series, with clay soil, sandy soil and sphagnum peat soil in three of the series and various compounds of clay soil and sphagnum peat in the remaining three. The compound series are not included in this report.

Laboratory tests of the three main soil types show the following: 


\begin{tabular}{|c|c|c|c|c|c|c|c|c|}
\hline \multirow{2}{*}{$\begin{array}{c}\text { Soil } \\
\text { series }\end{array}$} & \multirow{2}{*}{$\mathrm{pH}$} & \multirow{2}{*}{$\begin{array}{c}\text { Org. mat. } \\
\%\end{array}$} & \multicolumn{4}{|c|}{$\%$ of air dried soil } & \multirow{2}{*}{$\begin{array}{c}\text { Percentage } \\
\text { base satu- } \\
\text { ration }\end{array}$} & \multirow{2}{*}{$\begin{array}{c}\text { Cation } \\
\text { exchang } \\
\text { capacity }\end{array}$} \\
\hline & & & $2-0.2$ & $0.2-0.02$ & $0.02-0.002$ & $<0.002$ & & \\
\hline I & 5.0 & 7.9 & 3 & 10 & 41 & 38 & 5.6 & 22.4 \\
\hline $\mathrm{V}$ & 3.7 & 79.6 & - & - & - & - & 4.8 & 108.7 \\
\hline VI & 5.0 & 2.9 & 78 & 11 & 4 & 4 & 3.5 & 7.4 \\
\hline
\end{tabular}

Each soil series has been combined with two treatments for lime, where the lime rates were chosen on the basis of previous laboratory tests of varying lime rates.

Table 1. $\mathrm{pH}$ in the different soil series by different liming ( $\mathrm{A}=$ light liming, $\mathrm{B}=$ heavy liming). The figures of $\mathrm{pH}$ refer to treatment $\mathrm{a}=$ control (without addition of any heavy metal).

\begin{tabular}{|c|c|c|c|c|c|}
\hline \multirow{2}{*}{\multicolumn{2}{|c|}{ Soil series and soil types }} & \multicolumn{2}{|c|}{$\mathrm{CaCO}_{3} \mathrm{~g}$ per pot } & \multicolumn{2}{|c|}{$\mathrm{pH}$ after harvesting } \\
\hline & & A & B & A & B \\
\hline I. & Clay soil.............. & 5.0 & 25.0 & 5.50 & 6.48 \\
\hline V. & Sphagnum peat soil . & 12.5 & 25.0 & 5.25 & 7.15 \\
\hline VI. & Sandy soil .............. & 0 & 12.5 & 5.53 & 7.20 \\
\hline
\end{tabular}

Table 1 shows that the lime rate applied in B is too low for the clay soil. It might be noted that by slight liming (A), the high rate of cadmium has raised the $\mathrm{pH}$ in all the series, while the high rate of nickel has reduced it. This relates to nearly all cases, whether compared to the control or to application of other metals.

The heavy metals cadmium, cobalt, lead, mercury and nickel have been separately applied at rates of 0,50 and $250 \mathrm{mg}^{\text {per }}$ pot $^{1}$ ), respectively, combined with each of the two lime amounts. All heavy metals are applied in the form of chloride. In addition to the plant production experiment, an experiment pot without plants has been included in all treatments, from which soil samples will be taken for chemical analysis to elucidate how the bindings of the heavy metals alter with time in the various soil series.

\section{Crop yields}

The plant production experiment has been conducted in two parallels for each treatment, and harvested when the oats reached full ripeness. Yields of dry matter of grain and straw appear from Table 2.

1) Corresponds to 20 and $100 \mathrm{~kg}$ per hectare, respectively. 
Table 2. Yield, g dry matter per 5 litre pot.

\begin{tabular}{|c|c|c|c|c|c|c|c|c|c|c|c|c|c|c|c|}
\hline \multirow{4}{*}{$\begin{array}{l}\text { Heavy } \\
\text { metals }\end{array}$} & \multirow{4}{*}{ Series } & \multirow{4}{*}{\multicolumn{2}{|c|}{ Soils }} & \multicolumn{6}{|c|}{ Grain } & \multicolumn{6}{|c|}{ Straw } \\
\hline & & & & \multicolumn{3}{|c|}{ Light liming } & \multicolumn{3}{|c|}{ Heavy liming } & \multicolumn{3}{|c|}{ Light liming } & \multicolumn{3}{|c|}{ Heavy liming } \\
\hline & & & & \multicolumn{6}{|c|}{ Heavy metal added, $g$ per pot } & \multicolumn{6}{|c|}{ Heavy metal added, g per pot } \\
\hline & & & & 0 & 50 & 250 & 0 & 50 & 250 & 0 & 50 & 250 & 0 & 50 & 250 \\
\hline \multirow{3}{*}{ Cd } & I. & Clay s & soil ...... & 26.1 & 28.8 & 24.1 & 28.2 & 27.4 & 22.2 & 19.9 & 20.6 & 19.9 & 20.6 & 21.1 & 21.0 \\
\hline & V. & Peat s & soil .... & 28.2 & 28.4 & 27.8 & 32.4 & 31.9 & 29.9 & 32.9 & 29.9 & 23.3 & 34.6 & 32.6 & 25.7 \\
\hline & VI. : & Sandy & y soil .... & 25.6 & 23.7 & 23.3 & 22.6 & 23.5 & 25.2 & 23.7 & 27.6 & 24.6 & 22.2 & 25.2 & 20.7 \\
\hline \multirow{3}{*}{$\mathrm{Ni}$} & I. & Cl. s. & .......... & 26.1 & 26.4 & 10.4 & 28.2 & 26.7 & 28.6 & 19.9 & 19.0 & 8.3 & 20.6 & 20.0 & 20.5 \\
\hline & V. & P. s. & .......... & 28.2 & 30.8 & 7.3 & 32.4 & 33.0 & 31.0 & 32.9 & 32.4 & 9.3 & 34.6 & 33.9 & 26.6 \\
\hline & VI. & S. s. & .......... & 25.6 & 23.5 & 8.6 & 22.6 & 22.0 & 23.5 & 23.7 & 22.2 & 9.8 & 22.2 & 21.3 & 24.4 \\
\hline \multirow{3}{*}{$\mathrm{Hg}$} & I. & Cl. s. & & 26.1 & 28.7 & 20.8 & 28.2 & 30.3 & 27.2 & 19.9 & 20.9 & 15.2 & 20.6 & 21.9 & 19.1 \\
\hline & V. & P. s. & .......... & 28.2 & 30.8 & 24.9 & 32.4 & 34.8 & 25.2 & 32.9 & 31.0 & 23.4 & 34.6 & 32.5 & 21.5 \\
\hline & VI. & S. s. & ........... & 25.6 & 20.0 & 0 & 22.6 & 18.6 & 0 & 23.7 & 21.6 & 2.9 & 22.2 & 183 & 2.6 \\
\hline \multirow{3}{*}{$\mathrm{Pb}$} & I. & Cl. s. & & 26.1 & 25.9 & 25.6 & 28.2 & 27.0 & 28.0 & 19.9 & 19.5 & 20.0 & 20.6 & 19.9 & 20.0 \\
\hline & V. & P. s. & ..... & 28.2 & 29.3 & 30.1 & 32.4 & 33.1 & 33.2 & 32.9 & 31.7 & 31.9 & 34.6 & 33.6 & 34.4 \\
\hline & VI. & S. s. & n....... & 25.6 & 23.3 & 25.4 & 22.6 & 23.1 & 22.2 & 23.7 & 24.6 & 25.2 & 22.2 & 21.5 & 24.5 \\
\hline \multirow{3}{*}{ Co } & I. & Cl. s. & & 26.1 & 25.4 & 16.8 & 28.2 & 28.9 & 16.9 & 19.9 & 19.5 & 13.2 & 20.6 & 21.8 & 20.6 \\
\hline & v. & P. s. & .......... & 28.2 & 29.6 & 26.4 & 32.4 & 32.8 & 30.4 & 32.9 & 31.3 & 23.9 & 34.6 & 33.0 & 27.6 \\
\hline & VI. & S. s. & n........ & 256 & 24.1 & 19.7 & 22.6 & 22.2 & 20.6 & 23.7 & 22.7 & 22.0 & 22.2 & 22.1 & 26.5 \\
\hline
\end{tabular}

Grain and straw have, on the whole, reacted identically to the experimental treatment, though certain exceptions occur. The main features of the effect of the metals on the crop yield are as follows:

The smallast amount of metal (50 $\mathrm{mg}$ per pot) has in most cases had no effect on the yield size. Mercury forms an exception in series VI where a slight yield reduction is found with both lime amounts. This corresponds well with the fact that mercury in large amounts has induced an almost total crop failure in the same series, and more severe damage than any other metal in any series. A slight reduction both in grain and straw by light liming in the same soil series after the low addition of nickel also indicates an approach to the tolerance limit of oats for this metal, seen in relation to the considerable reduction induced by the high rate of nickel.

The high addition (250 mg per pot) has led to reduced crops for several metals:

Cadmium combined with heavy liming in series I (clay soil) has reduced the grain yield somewhat without affecting the straw yield. The reduction in straw yield in series $\mathrm{V}$ (peat soil) is, however, considerable at both degrees of liming, whereas the grain yield only shows slight reduction by heavy liming. The sandy soil shows no yield reduction after cadmium application. Nickel has induced heavy yield reduction of both grain and straw after light liming in all three series. Heavier liming has eliminated the detrimental effects completely 
in the series I and VI, while series V also shows some straw yield reduction after heavier liming. Mercury, as mentioned above, has induced an almost total yield failure in the sandy soil. The clay soil and sphagnum peat soil series have been far less affected, though some yield reduction appears here as well. Thus, both grain and straw yields have been reduced at both lime levels in sphagnum peat soil, while the clay soil only shows yield reduction at light liming. Lead has had no effect whatever on the yield size.

Cobalt has affected the various soil series in different ways. Series I shows considerable yield reduction. The grain yield is quite heavily reduced at both lime levels, and the straw yield is reduced at light liming. Series V shows only an indication of reduced grain yield, but an obviously reduced straw yield at both lime levels. Series VI only shows grain yield reduction at light liming.

Heavy metals in the crops

The contents of applied heavy metals have been determined for grain and straw separately at the Central Institute for Industrial Research, Oslo, under the supervision of Dr Gulbrand Lunde. Of the processes Lunde declares: "The content of cobalt, cadmium, nickel and lead was determined by atomic absorption spectrophotometer. A sample of $10-15 \mathrm{~g}$ was weighed and ashed in a quartz crucible, previously boiled in $6 \mathrm{~N} \mathrm{HCl}$, rinsed in destilled water and placed in a drying cabinet. The incineration was performed at $450^{\circ} \mathrm{C}$ for 12 hours. The evaporation of volatile compounds such as $\mathrm{PbCl}_{2}$ thereby fails to be registered (GoRSUCH, 1959). The ash remainder was weighed and treated with $2.5 \mathrm{ml}$ conc. $\mathrm{HCl}$. In some cases this gave too low a lead recovery $(10-$ $20 \%$ too low), and after some trials the method was modified. After the modified method the ash was boiled under reflux for 2 hours with $10 \mathrm{ml}$ concentrated $\mathrm{HNO}_{3}$. This gave an adequate recovery of lead as well as other elements. In the cases where $\mathrm{HCl}$ was applied to dissolve the ash, both the filtrate and the undissolved fraction were subject to control analysis by emission spectrography.

$\mathrm{HCl}$ and $\mathrm{HNO}_{3}$ extraction of the ash gave corresponding results for nickel and cobalt. Cobalt, cadmium, nickel and lead were directly determined in the solution by atomic absorption using a deuterium background corrector.

For mercury determination $0.2 \mathrm{~g}$ test material was treated by a $\mathrm{HNO}_{3}$ $+\mathrm{HBr}$ combustion. The mercury was then determined by flameless atomic absorption."

Table 3 shows the relative content of applied heavy metals in oats. Apart from lead, the relative content of metals in all soil series increases very heavily with increased metal application. At the high rate, the content in some cases increases several hundred times compared to the control. The content of the control varies somewhat within the different series. In the case of very low values these variations should be regarded with reservations. In certain cases, however, the variations are almost beyond doubt an expression of the capacity of different soil types for transferring heavy metals to the plants in a natural state. With regard to nickel, the content in the grain is notably higher in 


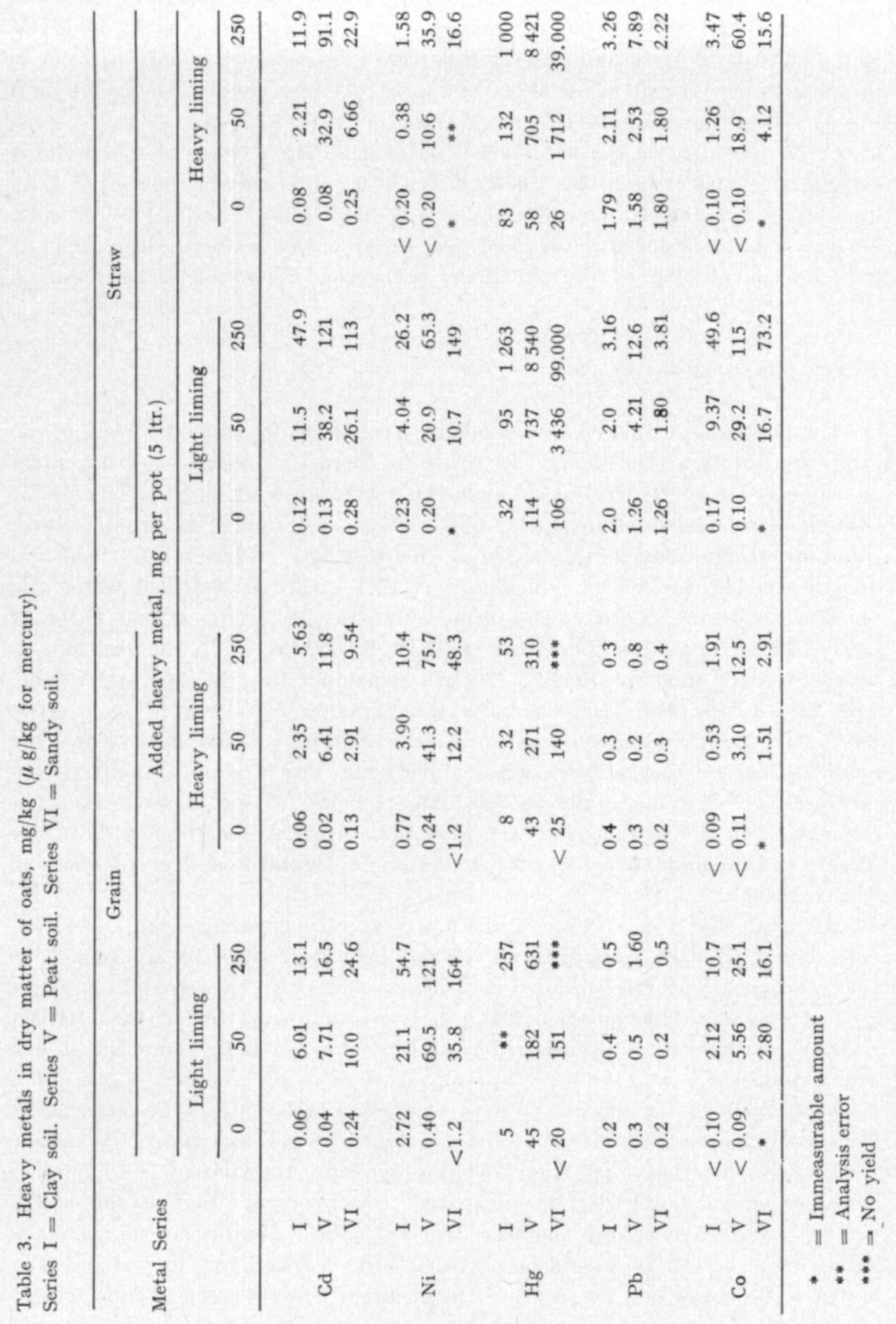


series I than in series V. The content of cadmium is notably higher in series VI than in series I and V.

After the metal application the content in the yield from the different series varies considerably at times. Beyond doubt real variations occur. When estimating the relative content it is important to be aware of the fact that it may increase with the reduced yield caused by metal application. The extremely high content of mercury in straw in series VI at the high rate serves to illustrate this relation.

Clay soil shows lower relative contents than the other two soil types after all metal applications except lead. This appears reasonable in comparison with the sandy soil series, in view of the much higher cation exchange capacity of clay soil. When peat soil, which has a high cation exchange capacity, has produced plants of quite a high metal content in parts, allowance should be made for the fact that the density of peat soil is equivalent to only about $1 / 11$ of that of clay soil and to about 1/17 of sandy soil. Peat soil therefore has correspondingly higher amounts of metals applied to it, calculated on weight basis, than have the mineral soils.

In the cases of cadmium, nickel and cobalt the relative content in the yield is practically without exception lower after heavy compared to light liming. This is evident even without metal application, after application the difference increases appreciably at times. Excluding the high rate of metal application, which in some cases has drastically affected the yield size, it appears that also after the low metal rate $(50 \mathrm{mg}$ per pot) the content in the yield may be strongly reduced by liming. The reductions are somewhat greater in the series I and VI than in series $\mathrm{V}$. In the former series the reduction in cadmium thus reaches $60-80$ per cent, in nickel $80-90$ per cent, while the cobalt content is reduced by $50-90$ per cent. In series $\mathrm{V}$, the reduction of the same metals at heavier liming is $15-20$ per cent, $40-50$ per cent, and 30 per cent, respectively.

The effect of heavy liming on the absorption of mercury and lead is equivocal.

Numerous investigations have stated that a low $\mathrm{pH}$ increases the lead uptake in the plants as well as the risk of lead toxicity (NorsBers 1968, MAC Lean 1969, Warren 1970). PAGe and Ganje (1972) found that no consistent trends occurred in the lead concentrations in leaves in relation to soil $\mathrm{pH}$, but that increasing the $\mathrm{pH}$ decreased the lead in the roots of the plants.

ANDERSSON (1967) in his investigations of mercury found its adsorption in the soil depended on the $\mathrm{pH}$, though with the distinction that adsorption in inorganic matter was highest between $\mathrm{pH} \mathbf{7 - 8}$, while the adsorption in the case of organic matter shifted notably to the acid area. The relation between organic and inorganic matter in the soil should thus be decisive for the mercury uptake with regard to the $\mathrm{pH}$ value.

After heavy application, the increase of many elements is often found to be highest in the vegetative parts of the plant. Apart from nickel, the content of metals included in this investigation is practically without exception higher in the straw than in the grain, with or without metal addition. Without addition, lead shows the widest difference with 4-10 times the content in straw compared to grain. HAMAR (1974) found a considerably higher lead content in the straw than in grain both in barley and oats in a pot experiment 
with the addition of sewage sludge. The same was noted by NosBers (1968) of summer rye, and TSO et al. (1968) found a much higher level of lead in tobacco leaf than in the seed.

The distribution of nickel uptake shows a different pattern, with an essentially higher content in the grain than in the straw with nickel application as well as without it. In pot experiments with sewage sludge SorTEBERG (1972) and HAMAR (1974) found a relative amount several times higher in grain than in straw. Hamar also included barley, but found no such difference for that species. Nosbers (1968) found about twice the nickel content in grain as in straw in summer rye after considerable nickel addition, whereas approximately the reverse was the case in treatments without nickel application.

\section{Soil analysis}

At harvesting time soil samples were taken from the pots without plants. From these soil samples and samples taken prior to the experiment, chemical analyses have been made by the National Swedish Laboratory for Agricultural Chemistry, Ultuna, Sweden. The metal contents have been determined in two different soil extracts, prepared as follows:

1. Soil extracted with an AL-solution (H. Egner et al.)

2. Soil extracted by $2 \mathrm{~N} \mathrm{HCl}$

(Kungl. lantbruksstyrelsens kungörelser m.m., 1965)

The amount extracted by the AL-solution may be expressed as relatively easily soluble metal, while the hydrochloric acid extraction also releases considerably more heavily soluble fractions.

Below is a list of various metal contents extracted by hydrochloric acid from the soil prior to treatment. The AL-soluble metal content has not been included, the content being too low to be determined with any reasonable degree of accuracy. The figures below refer to $\mathrm{mg}$ per $\mathrm{kg}$ air-dried soil.

\begin{tabular}{|c|c|c|c|c|c|}
\hline Soil series & $\mathrm{Cd}$ & $\mathrm{Ni}$ & $\mathrm{Hg}$ & $\mathrm{Pb}$ & Co \\
\hline I. Clay soil .................... & $<0,3$ & 29 & $<0,3$ & 34 & 14 \\
\hline V. Peat soil ................... & $<0,5$ & $<5$ & $<0,5$ & 7 & $<5$ \\
\hline VI. Sandy soil ................... & 0,4 & 7 & $<0,1$ & 15 & 5 \\
\hline
\end{tabular}

The present values lie within the range normally presented in the literature for contents in unpolluted soil. With regard to cadmium, BowEN (1966) presents a mean value content of $0.06 \mathrm{mg} / \mathrm{kg}$ (variation range $0.01-0.7$ ), while BERRow and WeBBER (1972) regard $0.1 \mathrm{mg} / \mathrm{kg}$ a normal content level. The nickel content in soil is set (BOWEN 1966) at $40 \mathrm{mg} / \mathrm{kg}$ soil mean value $(10-1000)$. SAUchelly (1969), however, regards $10-40 \mathrm{mg}$ as normal. 
Similar contents $(5.5-38.6 \mathrm{mg} / \mathrm{kg})$ are also given by SCHARRER (1955), based on investigations by Bertrand and Moksagnatz.

For mercury, Andersson (1967) investigating 273 soil samples in Sweden, found a mean value of $0.061 \mathrm{mg} / \mathrm{kg}(0.004-0.922 \mathrm{mg} / \mathrm{kg})$. The content was slightly higher in cultivated soil $(0.064 \mathrm{mg})$ than in uncultivated soil $(0.057)$. Some 600 samples of Norwegian forest humus soil showed $0.02-0.55 \mathrm{mg} / \mathrm{kg}$ (LÁ 1972). The lead content in soil is reported by BowER (1966) at a mean value of $10 \mathrm{mg} / \mathrm{kg}$ dry soil $(2-200)$, and by NosBERs (1968) at an average of $5-50 \mathrm{mg} / \mathrm{kg}$, rarely exceeding $100 \mathrm{mg} / \mathrm{kg}$. LÅ and BeLviken (1974) have investigated forest soil in Nøssmarka in Snertingdal. In unpolluted soil, the lead content showed a mean value of $\mathbf{5 7} \mathrm{mg} / \mathrm{kg}$ dry matter at $2-\mathbf{5} \mathrm{cm}$ depth (15 samples), and $26 \mathrm{mg} / \mathrm{kg}$ dry matter at $20-25 \mathrm{~cm}$ depth (16 samples). SCHARRER (1955) (with reference to Bertrand and Moksagnatz) puts the cobalt content at $0.26-11.7 \mathrm{mg} / \mathrm{kg}$ soil, while Bowen (1966) gives $8 \mathrm{mg} / \mathrm{kg}$ as the mean value (var.range $1-40$ ).

Table 4 shows the content of heavy metals in the experimental soils extracted with an AL-solution. The figures for hydrochloric acid extraction are not included in the table, since most figures show that approximately all of the added element, at times even more, has been recovered. Several figures from the soil series VI analysis thus show an increased metal content which in fact exceeds the amount added.

There is a wide difference in the content of AL-soluble metal fraction within the metals, the amount of metal added, and the soil type. Practically no added mercury has been recovered after the low addition. This applies to all soil types. In series $\mathrm{V}$ (peat soil) only traces of the added metal have been recovered even after a high rate of mercury. In series I (clay soil) and series VI (sandy soil), amounts equivalent to approximately $1-2$ per cent of the added metal have been recovered as AL-soluble. The highest amount of AL-soluble mercury has been recovered from the sandy soil, the soil type which almost completely failed in crop production (with repeated crop failure also in 1974). The recovery of only a few milligrammes per pot as AL-soluble should however, be seen in relation to the metal uptake of the plants, which in no case has exceeded $0.3 \mathrm{mg} \mathrm{Hg}$ per pot.

Of the added lead only a portion has been recovered as AL-soluble. At the maximum application, an amount ranging from slightly above 10 to barely 20 per cent has been recovered, the lowest recovery being found in clay soil. Comparing peat soil with sandy soil, the former soil type has about 15 times the cation exchange capacity but only about $1 / 17$ of the density of sandy soil. Alternately one or the other of these soil types show a higher amount of easily soluble metals, although with the specification that peat soil shows essentially higher amounts of easily soluble cobalt at the high added rate than does sandy soil. The figures deriving from the soil analysis offer no explanation of the distinct, though moderate crop reductions following a heavy cobalt application, most apparent in clay soil.

Of cadmium and nickel, from 20 to approximately 60 per cent of the low addition of the metal has been recovered as $\mathrm{AL}$-soluble. At the high rate application, an amount in excess of 40 to approximately 100 per cent (sandy soil) 
Table 4. Content of heavy metals in soils extracted with AL-solution, mg per pot.

\begin{tabular}{|c|c|c|c|c|c|c|c|c|c|c|c|}
\hline \multirow{4}{*}{ 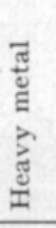 } & \multirow{4}{*}{ 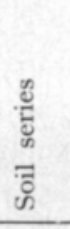 } & \multicolumn{3}{|c|}{ Light liming } & \multicolumn{3}{|c|}{ Heavy liming } & \multicolumn{2}{|c|}{ Light liming } & \multicolumn{2}{|c|}{ Heavy liming } \\
\hline & & \multicolumn{10}{|c|}{ Added heavy metals, mg per pot } \\
\hline & & 0 & 50 & 250 & 0 & 50 & 250 & 50 & 250 & 50 & 250 \\
\hline & & \multicolumn{6}{|c|}{ Content in soil, mg per pot } & \multicolumn{4}{|c|}{ Cont. in soil $\div$ control, $\mathrm{mg}$ per pot } \\
\hline \multirow{3}{*}{$\mathrm{Cd}$} & I & $<0.841$ & 21.0 & 63.1 & $<0.841$ & $21.0:$ & 58.8 & 20 & 62 & 20 & 58 \\
\hline & V & $<0.169$ & 32.1 & 167 & $<0.169$ & 29.5 & 165 & 32 & 167 & 29 & 165 \\
\hline & VI & $<0.129$ & 12.9 & 245 & $<1.29$ & 12.9 & 155 & 11 & 244 & 11 & 154 \\
\hline \multirow{3}{*}{$\mathrm{Ni}$} & I & $<8.41$ & 25.2 & 115 & $<0.841$ & 12.6 & 54.7 & 17 & 107 & 12 & 54 \\
\hline & V & 1.69 & 32.1 & 171 & 1.69 & 25.3 & 166 & 30 & 169 & 24 & 164 \\
\hline & VI & $<12.9$ & 32.2 & 193 & 12.9 & 25.8 & 122 & 19 & 180 & 23 & 109 \\
\hline \multirow{3}{*}{$\mathrm{Hg}$} & I & $<0.420$ & $<0.841$ & 4.20 & $<0.420$ & $<0.841$ & 2.10 & - & 4 & - & 2 \\
\hline & V & $<0.084$ & $<0.084$ & 0.211 & $<0.084$ & $<0.084$ & $<0.211$ & - & + & - & + \\
\hline & VI & $<0.644$ & $<0.644$ & 6.44 & $<0.644$ & $<0.644$ & 6.44 & - & 6 & - & 6 \\
\hline \multirow{3}{*}{$\mathrm{Pb}$} & I & $<0.420$ & 0.841 & 33.6 & $<0.420$ & 0.841 & 29.4 & - & 33 & $\overline{-}$ & 29 \\
\hline & $\mathrm{V}$ & 1.35 & 9.71 & 44.8 & 1.35 & 12.2 & 42.2 & 8 & 43 & 11 & 41 \\
\hline & VI & $<6.44$ & 25.8 & 51.5 & $<6.44$ & $<6.44$ & 51.5 & 19 & 45 & - & 45 \\
\hline \multirow{3}{*}{ Co } & I & $<0.841$ & 21.0 & 109 & $<0.841$ & 8.41 & 33.6 & 20 & 108 & 8 & 33 \\
\hline & V & $<1.69$ & 35.0 & 189 & $<1.69$ & 33.8 & 177 & 33 & 187 & 32 & 175 \\
\hline & VI & $<12.9$ & 45.1 & 116 & $<12.9$ & 19.3 & 83.7 & 32 & 103 & 6 & 71 \\
\hline
\end{tabular}

and 70 per cent (sphagnum peat soil) has been recovered as AL-soluble and in clay soil from approximately 20 to approximately 40 per cent.

As mentioned above, the plant uptake of cadmium, nickel and cobalt has been notably reduced by heavy liming. The AL-soluble amounts of the same metals in soil also vary with liming. In peat soil, only a slight reduction has been found for all three metals after increased liming. The AL-soluble fractions of the same metals are, however, in general severely reduced after heavy liming in clay soil and sandy soil. In the case of nickel, clay soil and sandy soil gave yield sizes corresponding with the AL-soluble fraction (noticeably higher yields and less AL-soluble nickel in the soil after heavy liming compared to light liming). In peat soil, however, the yield size corresponds more closely with the obviously reduced plant uptake after heavy liming, than with the content of AL-soluble metals in the soil.

Retarded growth and symptoms of toxicity

Some of the metals have in one or more series induced considerable growth retardment and yield reduction at the high rate of metal addition $(250 \mathrm{mg}$ per pot). On occasions, definite symptoms of toxicity have been evident, particularly from well past germination to about the tillering stage. 
Cadmium. Obvious growth retardment before shooting, but no definite symptoms.

Cobalt. Varying degrees of growth retardment in all soil series. Most pronounced after heavy liming. Definite symptoms are only observed in series V (sphagnum peat soil). The oats here developed conspicuous interveinal chlorosis at both rates of lime. The chlorosis clearly resembles the iron deficiency in oats grown in iron deficient sphagnum peat soil. The present case indicates a cobalt induced iron deficiency.

Lead. No deviation from normal growth and development.

Mercury. More or less pronounced growth retardment and yield reduction in all series, particularly after light liming. Series VI (sandy soil) stands out with near crop failure. The cotyledon acquired a distinct purple colour even at an early stage.

Nickel. Pronounced growth retardment and yield reduction in all series after light liming. Slender plants and acute angles between stem and leaf body. White elongated lines and white spots gradually developed on older leaves. The symptoms sometimes appeared first on the cotyledon, sometimes on younger leaves. The spots often spread across the entire leaf. At times the leaf might show two or more sharply defined white green leaf tissue in between. The cotyledon gradually developed a sharp purple colour and wilted wholly or partially.

\section{REFERENCES}

ANdersson, A. 1967. Grundförbättring 20, 3-4: 95-105.

Borrow, M. L. \& WebBer, J. 1972. J. Sci. Food Agric. 23: 93-100.

Bowen, H. J. 1966. Trace Elements in Biochemistry. 241 p. London-New York.

Gorsuch, T. T. 1959. Radiochemical Investigations on the Recovery for Analysis of Trace Elements in Organic and Biological Materials. The Analyst. 84:135.

Hamar, T. O. 1974. Kloakkslam til plantedyrking. Hovedoppgave NLH. 127 p.

Kungl. Lantbruksstyrelsens Kungorelser m.m. 1965 nr. 1, 20 p.

LÁG, J. 1972. Norsk jordbunnsforskning i relasjon til problemer om naturforurensning med tungmetaller. Symposium om tungmetaller, Hurdal. p. 52-58.

_- - \& B2LVIKEN, B. 1974. Some naturally heavy-metal poisoned areas of interest in prospecting soil chemistry, and geomedicine. Norges Geol. Unders. 304: 73-96.

Mac Lean, A. J., Halstead, R. L. \& Finn, B. J. 1969. Extractability of added lead in soils and its concentration in plants. Can. J. Soil Sci. 49: 327.

Nosbers, R. 1968. Die Aufnahme von Blei, Chrom, Nickel und Zink durch landwirtschaftliche Nutzpflanzen bei Anwendung von Abwasserklärschlam. Dissert. 93 p. Bonn.

PAGE, A. L. \& GANJE, T. J. 1972. Influence of applications of highway residues to soils on growth and lead content of plants. Agron. Soc. Am., 88.

SAUChelly, V. 1969. Trace Elements in Agriculture. 248 p. New York, Cincinnati, Toronto, London, Melbourne.

Scharrer, K. 1955. Biochemi der Spurenelemente. 404 p. Paul Parey on Berlin und Hamburg.

Sorteberg, A. 1972. Kloakkslam og tungmetaller. Inst. f. jordkultur. Saertr. 120.

Tso, T. C., Carr, J. M., Ferri, E. S., \& Baretta, E. J. 1968. Agronomic factors affecting polonium -210 and lead -210 levels in tobacco. I. Varieties and curing methods. Agron. J. 60: 647. 


\title{
Eräiden raskaiden metallien vaikutuksesta ohran kasvuun
}

\author{
AsBjørn Sørteberg \\ Norjan maatalouskorkeakoulu
}

Astiakokeena tutkittiin kadmiumin, koboltin, lyijyn, elohopean ja nikkelin vaikutusta ohran kasvuun. Näitä metalleja lisättiin 5 litran astioihin 0,50 tai $250 \mathrm{mg}$. Koemaita oli kolme: hiesusavi ( $\mathrm{pH}$ 5.0), rahkaturve ( $\mathrm{pH}$ 3.7) ja hiekka ( $\mathrm{pH}$ 5.0). Myōs kalkitus oli koetekijänä. Pienemmällä $\mathrm{CaCO}_{3}$-määrällä koemaiden $\mathrm{pH}$ nostettiin välille $5.3-5.5$ ja suuremmalla määrällä välille $\mathrm{pH}$. $6.5-7.2$.

Pienempi metallilisäys (50 mg/astia) ei juuri vaikuttanut ohrasadon määräăn. Suurempi metallimäärä (250 mg/astia) sensijaan aiheutti selviä sadonalennuksia. Tällöin nikkeli alensi koemaasta riippumatta voimakkaasti sekä jyvä- että olkisatoa, jos oli käytetty pienempää kalkkimäärää. Voimakas kalkitus pystyi lähes täysin estämään sadonalennuksen. Elohopealisäys esti kalkituksesta huolimatta ohran kasvun lähes täydellisesti hiekkamaassa. Runsaampi elohopeamäärä alensi myös turvemaan satoa mụtta savimaan satoa vain alemmalla kalkitustasolla. Kadmium alensi olkisatoa kummallakin kalkitustasolla turvemaassa ja jyväsatoa korkeammalla kalkitustasolla savimaassa, mutta hiekkamaan ohrasatoon kadmium ei vaikuttanut. Koboltti aiheutti jossain määrin sadon alennusta kaikissa maalajeissa, eniten lievästi kalkitussa savessa. Lyijyllä ei ollut vaikutusta sadon määrään.

Lyijyä lukuunottamatta raskaiden metallien lisääminen maahan lisäsi voimakkaasti niiden pitoisuutta ohrasadossa. Metallipitoisuudet lisääntyivät voimakkaammin turve- ja hiekkamaan kuin savimaan ohrassa. Kalkitus alensi etenkin savi- ja hiekkamaan ohran kadmiumin, nikkelin ja koboltin pitoisuuksia. Nikkeliä lukuunottamatta metallien pitoisuudet olivat yleensä korkeampia oljissa kuin jyvissä. Erityisesti tämä koski lyijyä.

Tutkimuksessa selvitettiin myös maahan lisättyjen metallien uuttumista AL-(ammoniumlaktaatti-)uutteeseen. Tätä varten kokeessa oli mukana kasvittomia maa-astioita, joista sadonkorjuuaikana otettiin maanäytteet analyysejä varten. AL-liukoiset elohopeamäärät olivat vain 1-2\% lisätyistä määristä. Samoin lyijyn osalta "saaliit olivat varsin pieniä. Muita metalleja uuttui yleensä $20-70 \%$ lisätyistä määristä. Suurimmat määrät saatiin tavallisesti turvemaasta, pienimmät savimaasta.

Tutkimukseen sisältyy kuvaus metallien toksisista vaikutuksista ohran kehitykseen.

1) Selostuksen laatinut P. Elonen 